\title{
HUBUNGAN PENDIDIKAN DI DALAM KELUARGA TERHADAP PERILAKU PENGEMUDI KENDARAAN BERMOTOR SAAT BERLALU LINTAS
}

\author{
Yendi Fajar Alyandi ${ }^{1}$ dan Leksmono Suryo Putranto ${ }^{2}$

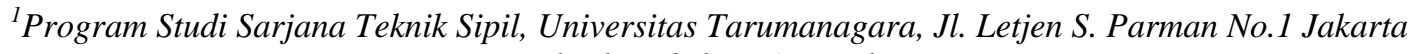 \\ Email:alyandi.fajar@gmail.com \\ ${ }^{2}$ Program Studi Sarjana Teknik Sipil, Universitas Tarumanagara, Jl. Letjen S. Parman No.1 Jakarta \\ Email: lexy@tarumanagara.ac.id
}

\begin{abstract}
ABSTRAK
Kecelakaan lalu-lintas di jalan raya masih memegang predikat pembunuh terbesar di dunia setelah penyakit jantung dan TBC. Perilaku ketidakdisiplinan masyarakat dalam berlalu-lintas merupakan penyumbang terbesar penyebab kecelakaan lalu-lintas dengan persentase $89,5 \%$. Diperlukan sebuah cara yang tepat untuk mengedukasi pengemudi kendaraan bermotor. Pendidikan di lingkungan keluarga merupakan pendidikan paling berpengaruh dibandingkan pendidikan lainnya, sehingga diharapkan dapat mengedukasi pengemudi kendaraan bermotor dalam berlalu-lintas. Penelitian ini bertujuan untuk mengetahui pengaruh antara pendidikan yang diajarkan di dalam keluarga terhadap perilaku pengemudi kendaraan bermotor saat berlalu-lintas. Pengumpulan data dilakukan menggunakan kuesioner online (67 orang) dan offline (49 orang) terhadap penduduk di jabodetabek berusia diatas 18 tahun. Kuesioner dibagi menjadi dua bagian, bagian pertama berisi tentang perilaku responden dalam berlalu-lintas dengan menggunakan sepeda motor atau mobil. Bagian kedua berisi tentang pendidikan di dalam keluarga berupa norma baik dan norma tidak baik lalu dikelompokkan menjadi norma agama, norma disiplin, etika dan sopan santun serta norma hukum. Analisis dilakukan untuk mengetahui pengaruh pendidikan dalam keluarga terhadap perilaku pengemudi kendaraan bermotor. Data yang dikumpulkan dianalisis menggunakan korelasi pearson product moment dengan software Stastistical Package for Social Science (SPSS). Hasil penelitian ini menunjukan perilaku positif responden pengemudi kendaraan bermotor. Pendidikan dalam keluarga sebagian besar tidak memiliki pengaruh dengan perilaku pengemudi sepeda motor. Sebaliknya pendidikan dalam keluarga memiliki pengaruh dengan perilaku pengemudi mobil.
\end{abstract}

Kata kunci: pendidikan, pendidikan keluarga, perilaku berlalu-lintas.

\section{PENDAHULUAN}

\section{Latar Belakang}

Transportasi merupakan kebutuhan yang sangat mendasar, terutama untuk daerah yang memiliki banyak aktivitas seperti pendidikan, hiburan, tempat tinggal dan lain sebagainya yang perlu disokong oleh sistem transportasi agar aktivitas tersebut dapat berjalan dengan baik. Namun transportasi juga memiliki nilai bahaya, salah satu nya ialah kecelakaan lalu lintas darat. Kecelakaan lalu lintas di jalan raya masih memegang predikat pembunuh terbesar ketiga di dunia setelah penyakit jantung dan TBC. Data Kepolisian RI tahun 2009 menyebutkan, sepanjang tahun terjadi sedikit nya 57.726 kasus kecelakaan di jalan raya, artinya dalam setiap 9,1 menit sekali terjadi satu kasus kecelakaan (Kementrian Perhubungan Republik Indonesia: 2011).

Menurut Sitorus dalam Dian (2016) penyebab kecelakaan lalu lintas di Indonesia yang paling besar adalah faktor manusia $89,5 \%$, dimana peran manusia sebagai pengemudi $82,39 \%$ dan sebagai pejalan kaki $7,11 \%$, faktor kendaraan $4,8 \%$, faktor jalan raya $5,05 \%$, dan faktor lingkungan $0,65 \%$.

Perilaku ketidakdisiplinan masyarakat dalam berlalu-lintas seperti mengendarai kendaraan melebihi batas kecepatan yang ditentukan, menerobos lampu lalu lintas, melewati marka pembatas jalan, tidak melengkapi alat keselamatan seperti halnya tidak menggunakan helmet, spion, lampu-lampu kendaraan, ketidaklengkapan surat-surat kendaraan bermotor, tidak taat membayar pajak, menggunakan kendaraan tidak layak pakai (Sadono: 2016).

Lingkungan keluarga merupakan lingkungan pendidikan yang paling berpengaruh dibandingkan yang lain, karena seorang anak yang lahir sejak awal kehidupannya, dan dalam keluargalah ditanamkan benih-benih pendidikan (Dimyati dan Mudjiono dalam Kristianto: 2012). Keluarga merupakan lingkungan pendidikan yang pertama, karena 
dalam keluarga inilah anak pertama-tama mendapatkan didikan dan bimbingan. Juga dikatakan lingkungan yang utama, karena sebagian besar dari kehidupan anak adalah di dalam keluarga sehingga pendidikan yang paling banyak diterima oleh anak adalah dalam keluarga (Hasbullah: 2009).

Oleh karena itu, peran pendidikan keluarga sangatlah penting dalam menjadikan seseorang dapat menjadi pribadi yang baik untuk lingkungan begitu juga didalam berprilaku berlalu lintas.

\section{Batasan Masalah}

Penulis membatasi masalah hanya pada pendidikan didalam keluarga terhadap perilaku pengemudi kendaraan bermotor saat berlalu lintas sehari-hari dan membatasi jenis kendaraan bermotor seperti perilaku mengendarai sepeda motor dan mobil.

\section{Rumusan Masalah}

Bagaimana pengaruh pendidikan di dalam keluarga terhadap perilaku pengemudi kendaraan bermotor saat berlalu lintas?

\section{Tujuan Penelitian}

Mengetahui apakah ada pengaruh antara pendidikan yang diajarkan di dalam keluarga dapat memengaruhi perilaku pengemudi kendaraan bermotor saat berlalu lintas.

\section{TINJAUAN PUSTAKA}

\section{Pendidikan Keluarga}

Pendidikan keluarga adalah proses pemberian positif bagi tumbuh kembangnya anak sebagai pondasi pendidikan selanjutnya (Mansur: 2005). Menurut Agus (2012) pendidikan dalam keluarga adalah pendidikan utama dan pertama bagi anak yang tidak bisa digantikan oleh lembaga pendidikan manapun. Keluarga dipandang sebagai penentu utama pembentukan kepribadian anak alasannya adalah keluarga merupakan kelompok sosial pertama yang menjadi pusat identifikasi anak, anak banyak menghabiskan waktunya di lingkungan keluarga. Para anggota keluarga merupakan "significant people" bagi pembentukan kepribadian anak (Yusuf: 2007).

\section{Perilaku Berlalu Lintas}

Perilaku berlalu lintas adalah dorongan yang berada dalam diri manusia yang meliputi perjalanan, gerak dari kendaraan tidak secara tiba-tiba dorongan tersebut dapat hilang pada saat tertentu. Akan tetapi perilaku berlalu lintas tersebut akan tetap ada kelangsungan atau kontinuitas antara satu perbuatan yang kemudian berkelanjutan pada perbuatan berikutnya yang berupa penarikan benda-benda yang dapat bergerak, angkutan penumpang, arus pejalan kaki, dan ditambah dengan beberapa kegiatan yang berhubungan penggunaan jalan umum (Buwana: 2013).

\section{Faktor dan Aspek yang Mempengaruhi Perilaku Berlalu Lintas}

Menurut Petridou dan Moustaki ada beberapa hal yang menjadi faktor dalam memengaruhi perilaku berlalu lintas adalah jalan yang berlubang dan kecelakaan lalu lintas; Faktor yang beresiko yang mempengaruhi perilaku pengemudi, seperti faktor perilaku, pengambilan resiko, stres, gangguan, kelelahan, pengalaman, usia, alkohol, narkoba, obat obatan dan penyakit (Buwana: 2013).

Sedangkan aspek-aspek perilaku berlalu lintas antara lain kelengkapan dalam surat-surat seperti Surat Izin Mengemudi (SIM) dan Surat Tanda Nomor Kendaraan (STNK), melanggar rambu-rambu lalu lintas dan perilaku mengendarai sepeda motor.

\section{METODOLOGI PENELITIAN}

\section{Metodologi Pengumpulan Data}

Untuk memperoleh data dilakukan dengan penyebaran kuesioner secara langsung (49 orang) dan online (67 orang) terhadap penduduk di Jabodetabek berusia diatas 18 tahun. Kuesioner dibagi menjadi dua bagian, bagian pertama berisi tentang perilaku responden dalam berlalu-lintas dengan menggunakan sepeda motor atau mobil. Bagian kedua 
berisi tentang pendidikan di dalam keluarga berupa norma baik dan norma tidak baik lalu dikelompokkan menjadi norma agama, norma disiplin, etika dan sopan santun serta norma hukum.

\section{Metodologi Analisis Data}

Untuk menganalisis kumpulan data yang disajikan ialah data responden gabungan dari responden yang mengisi kuesioner secara langsung maupun online. Analisis menggunakan korelasi Pearson Product Moment pada software SPSS versi 22. Analisis korelasi ini digunakan untuk melihat hubungan 2 kelompok kuesioner yaitu Motorcycle Rider Behaviour Questionnaires (MRBQ) dan Driver Behaviour Questionnaire (DBQ) yang dihubungkan dengan pendidikan didalam keluarga berupa norma. Indikator yang digunakan didalam MRBQ yaitu pelanggaran kecepatan, pelanggaran keselamatan, kesalahan mengendalikan kendaraan, kesalahan berlalu lintas, pelanggaran berlalu lintas dan melakukan aksi stunt. Sedangkan indikator yang digunakan didalam DBQ yaitu bersikap agresif, pelanggaran biasa, kesalahan dan penyimpangan dan indikator yang digunakan dalam kuesioner norma yaitu norma agama, norma disiplin, etika dan sopan santun serta norma hukum.

\section{HASIL ANALISIS DATA}

\section{Korelasi Kelompok Norma Dengan Kelompok Variabel MRBQ}

Data yang akan ditampilkan adalah hasil korelasi dari kelompok variabel norma dengan kelompok variabel MRBQ, disajikan dalam bentuk tabel yang terdiri dari norma agama, norma disiplin, etika dan sopan santun serta norma hukum yang dikorelasikan dengan kelompok variabel MRBQ. Analisis dilakukan dengan mengkorelasikan nilai mean norma dengan nilai mean kelompok variabel MRBQ.

\section{Korelasi Norma Agama Dengan Kelompok Varabel MRBQ}

Pada Tabel 1. terlihat yang hanya memiliki korelasi antara norma agama dengan kelompok variabel MRBQ ialah melakukan aksi stunt dengan nilai alpha 0,042. Stunt sendiri tumbuh berkembang di negara luar dan masuk ke Indonesia sebagai dampak globalisasi dan stunt dapat diartikan sebagai bergaya bebas dalam mengendarai sepeda motor atau beraksi dalam mengendarai sepeda motor. Seseorang yang melakukan aksi stunt cenderung dilakukan karena nafsu dalam nafs (jiwa) yang berdampak buruk pada pelaku maupun lingkungannya, lain hal nya ketika stunt dilakukan karena keahlian sehingga seseorang tersebut sudah dapat menguasai aksi stunt dan dapat mengetahui apa resiko yang dapat ditimbulkan.

Tabel 1. Korelasi Antara Norma Agama Dengan Kelompok Variabel MRBQ

\begin{tabular}{|c|c|c|c|}
\hline Kelompok Variabel & $\begin{array}{c}\text { Koefisien Korelasi } \\
(\mathbf{r})\end{array}$ & $\boldsymbol{\alpha}$ & $\begin{array}{c}\text { Signifikan? } \\
\text { (Ya/Tidak) }\end{array}$ \\
\hline Pelanggaran Kecepatan & 0,096 & 0,221 & Tidak \\
\hline Pelanggaran Keselamatan & $-0,202$ & 0,052 & Tidak \\
\hline Kesalahan Mengendalikan Kendaraan & 0,199 & 0,054 & Tidak \\
\hline Kesalahan Berlalu Lintas & 0,182 & 0,072 & Tidak \\
\hline Pelanggaran Berlalu Lintas & 0,098 & 0,216 & Tidak \\
\hline Melakukan aksi Stunt & 0,214 & 0,042 & Ya \\
\hline
\end{tabular}

\section{Korelasi Norma Disiplin Dengan Kelompok Variabel MRBQ}

Pada Tabel 2. terlihat yang hanya memiliki korelasi antara norma disiplin dengan kelompok variabel MRBQ ialah pelanggaran kecepatan dengan nilai alpha $<0,001$, kesalahan berlalu lintas dengan nilai alpha 0,024 dan melaukan aksi stunt dengan nilai alpha 0,008. Tampak nyata akan dampak dari kedisiplinan yang dimiliki seseorang memiliki nilai positif dalam beraktifitas maupun berkendara. Seperti dalam analisis diatas, disiplin dapat membentengi seseorang dari kegiatan pelanggaran kecepatan, kesalahan berlalu lintas dan melakukan aksi stunt. Kedisiplinan juga dapat tercermin dari aspek ketepatan waktu, ketaatan atau kepatuhan dan tanggungjawab.

Hal ini bersependapat dengan hasibuan, dalam (Lastriani: 2014) yang meyatakan definisi kedisiplinan yang baik yaitu: "kedisiplinan adalah kesadaran atau kesediaan seseorang mentaati semua peraturan organisasi atau perusahaan dan norma-norma sosial yang berlaku. Sejalan dengan itu pengertian disiplin berlalu lintas merujuk pada UU RI No. 22 Th. 2009 tentang lalu lintas dan angkutan jalan yang menerangkan bahwa segala perilaku pengguna jalan baik bermotor ataupun tidak di jalan raya yang sesuai dengan undang-undang ataupun peraturan lalu lintas yang telah ditetapkan. (Husada dan Sulaiman: 2016). 
Tabel 2. Korelasi Antara Norma Disiplin Dengan Kelompok Variabel MRBQ

\begin{tabular}{|c|c|c|c|}
\hline Kelompok Variabel & $\begin{array}{c}\text { Koefisien Korelasi } \\
(\mathbf{r})\end{array}$ & $\boldsymbol{\alpha}$ & $\begin{array}{c}\text { Signifikan? } \\
\text { (Ya/Tidak) }\end{array}$ \\
\hline Pelanggaran Kecepatan & 0,396 & $<0,001$ & Ya \\
\hline Pelanggaran Keselamatan & 0,020 & 0,438 & Tidak \\
\hline Kesalahan Mengendalikan Kendaraan & 0,118 & 0,172 & Tidak \\
\hline Kesalahan Berlalu Lintas & 0,245 & 0,024 & Ya \\
\hline Pelanggaran Berlalu Lintas & 0,128 & 0,154 & Tidak \\
\hline Melakukan aksi Stunt & 0,294 & 0,008 & Ya \\
\hline
\end{tabular}

\section{Korelasi Etika Dan Sopan Santun Dengan Kelompok Variabel MRBQ}

Pada Tabel 3. terlihat yang memiliki korelasi antara etika dan sopan santun dengan kelompok variabel MRBQ ialah pelanggaran kecepatan dengan nilai alpha 0,025, kesalahan mengendalikan kendaraan dengan nilai alpha 0,034 dan melakukan aksi stunt dengan nilai alpha 0,001. Hal ini dapat dijelaskan dengan perilaku responden yang memiliki etika dan sopan santun dapat menghindari diri dari aksi pelanggaran kecepatan, karena dimungkinkan responden telah mengerti bagaimana harus bersikap contohnya mematuhi batas kecepatan, tidak memacu kendaraan dengan cepat ketika ditikungan. Efek selanjutnya setelah responden dapat menghindari dari aksi pelanggaran kecepatan maka responden dengan mudah mengendalikan kendaraan yang digunakan, artinya responden dapat terhindar dari kesalahan mengendalikan kendaraan seperti kesulitan mengendalikan sepeda motor pada kecepatan tinggi, begitupun responden tidak akan melakukan aksi stunt ketika memiliki etika dan sopan santun yang tinggi.

Tabel 3. Korelasi Antara Etika dan Sopan Santun Dengan Kelompok Variabel MRBQ

\begin{tabular}{|c|c|c|c|}
\hline Kelompok Variabel & $\begin{array}{c}\text { Koefisien Korelasi } \\
(\mathbf{r})\end{array}$ & $\boldsymbol{\alpha}$ & $\begin{array}{c}\text { Signifikan? } \\
\text { (Ya/Tidak) }\end{array}$ \\
\hline Pelanggaran Kecepatan & 0,243 & 0,025 & Ya \\
\hline Pelanggaran Keselamatan & $-0,030$ & 0,404 & Tidak \\
\hline Kesalahan Mengendalikan Kendaraan & 0,226 & 0,034 & Ya \\
\hline Kesalahan Berlalu Lintas & 0,184 & 0,069 & Tidak \\
\hline Pelanggaran Berlalu Lintas & 0,185 & 0,068 & Tidak \\
\hline Melakukan aksi Stunt & 0,374 & 0,001 & Ya \\
\hline
\end{tabular}

\section{Korelasi Norma Hukum Dengan Kelompok Variabel MRBQ}

Pada Tabel 4. terlihat tidak ada satupun norma hukum yang berkorelasi dengan kelompok variabel MRBQ. Hal tersebut diluar dugaan dari peneliti, karena peneliti memperkirakan adanya pendidikan norma hukum yang diajarkan keluarga kepada seseorang akan memiliki dampak positif kepada responden agar dapat memahami setiap peraturanperaturan yang berlaku dalam berkendara dan dapat berkendara dengan baik.

Tabel 4. Korelasi Antara Etika dan Sopan Santun Dengan Kelompok Variabel MRBQ

\begin{tabular}{|c|c|c|c|}
\hline Kelompok Variabel & $\begin{array}{c}\text { Koefisien Korelasi } \\
(\mathbf{r})\end{array}$ & $\boldsymbol{\alpha}$ & $\begin{array}{c}\text { Signifikan? } \\
\text { (Ya/Tidak) }\end{array}$ \\
\hline Pelanggaran Kecepatan & 0,123 & 0,163 & Tidak \\
\hline Pelanggaran Keselamatan & 0,011 & 0,466 & Tidak \\
\hline Kesalahan Mengendalikan Kendaraan & 0,142 & 0,128 & Tidak \\
\hline Kesalahan Berlalu Lintas & $-0,041$ & 0,372 & Tidak \\
\hline Pelanggaran Berlalu Lintas & 0,191 & 0,062 & Tidak \\
\hline Melakukan aksi Stunt & 0,151 & 0,113 & Tidak \\
\hline
\end{tabular}

\section{Korelasi Kelompok Norma Dengan Kelompok Variabel DBQ}

Data yang akan ditampilkan adalah hasil korelasi dari kelompok variabel norma dengan kelompok variabel DBQ, disajikan dalam bentuk tabel yang terdiri dari norma agama, norma disiplin, etika dan sopan santun serta norma hukum yang dikorelasikan dengan kelompok variabel DBQ. Analisis dilakukan dengan mengkorelasikan nilai mean norma dengan nilai mean kelompok variabel DBQ. 


\section{Korelasi Norma Agama Dengan Kelompok Variabel DBQ}

Pada Tabel 5. terlihat yang memiliki korelasi antara norma agama dengan kelompok variabel DBQ ialah kesalahan dengan nilai alpha 0,035 dan penyimpangan dengan nilai alpha 0,034. Norma agama memberikan efek positif kepada responden untuk dapat menghindari dari kesalahan ketika mengendarai mobil yang menekankan responden untuk berdoa sebelum berkendara dan memberikan tingkat kepercayaan serta konsentrai dalam berkendara untuk menghindari dari penyimpangan yang mungkin terjadi seperti menggunakan telepon genggam yang dapat merugikan orang lain atau pengguna jalan lainnya. Namun diluar dugaan norma agama tidak memiliki korelasi dengan bersikap agresif, ketika seseorang memiliki agama yang baik maka responden dapat menjaga emosi atau perilaku yang baik juga.

Tabel 5. Korelasi Antara Norma Agama Dengan Kelompok Variabel DBQ

\begin{tabular}{|c|c|c|c|}
\hline Kelompok Variabel & $\begin{array}{c}\text { Koefisien Korelasi } \\
(\mathbf{r})\end{array}$ & $\boldsymbol{\alpha}$ & $\begin{array}{c}\text { Signifikan? } \\
\text { (Ya/Tidak) }\end{array}$ \\
\hline Bersikap Agresif & $-0,023$ & 0,438 & Tidak \\
\hline Pelanggaran Biasa & 0,137 & 0,171 & Tidak \\
\hline Kesalahan & 0,258 & 0,035 & Ya \\
\hline Penyimpangan & 0,261 & 0,034 & Ya \\
\hline
\end{tabular}

\section{Korelasi Norma Disiplin Dengan Kelompok Variabel DBQ}

Pada Tabel 6. terlihat yang memiliki korelasi positif antara norma disiplin dengan kelompok variabel DBQ ialah pelanggaran biasa dengan nilai alpha 0,016 dan kesalahan dengan nilai alpha 0,005. Tidak hanya dalam berkendara sepeda motor saja, ternyata norma disiplin memiliki korelasi yang positif dengan berperilaku berkendara mobil. Hal ini bisa dikarenakan responden taat dan sadar akan peraturan yang berlaku serta melaksanakannya dengan suka rela, contohnya ialah responden dengan jelas melakukan pengereman ketika lampu lalu lintas sudah berwarna merah, selalu menggunakan seatbelt ketika berkendara tanpa harus ditegur terlebih dahulu oleh polisi.

Tabel 6. Korelasi Antara Norma Disiplin Dengan Kelompok Variabel DBQ

\begin{tabular}{|c|c|c|c|}
\hline Kelompok Variabel & $\begin{array}{c}\text { Koefisien Korelasi } \\
(\mathbf{r})\end{array}$ & $\boldsymbol{\alpha}$ & $\begin{array}{c}\text { Signifikan? } \\
\text { (Ya/Tidak) }\end{array}$ \\
\hline Bersikap Agresif & 0,103 & 0,238 & Tidak \\
\hline Pelanggaran Biasa & 0,305 & 0,016 & Ya \\
\hline Kesalahan & 0,366 & 0,005 & Ya \\
\hline Penyimpangan & 0,097 & 0,252 & Tidak \\
\hline
\end{tabular}

\section{Korelasi Etika Dan Sopan Santun Dengan Kelompok Variabel DBQ}

Pada Tabel 7. sebagian besar etika dan sopan santun berkorelasi signifikan dengan kelompok variabel DBQ kecuali dengan bersikap agresif. Hal ini diluar dugaan peneliti yang memperkirakan adanya korelasi antara etika dan sopan santun dengan bersikap agresif, dikarenakan ketika responden memiliki nilai budi luhur yang baik pasti responden tersebut akan saling menghormati antar sesama pengguna jalan dan mengendalikan emosi dirinya ketika berkendara misalnya dapat menahan emosi ketika menemui atau berpapasan dengan pengendara lainnya yang dirasa merugikan dirinya atau tidak mengemudikan kendaraannya dengan ugal-ugalan.

Tabel 7. Korelasi Antara Etika dan Sopan Santun Dengan Kelompok Variabel DBQ

\begin{tabular}{|c|c|c|c|}
\hline Kelompok Variabel & $\begin{array}{c}\text { Koefisien Korelasi } \\
(\mathbf{r})\end{array}$ & $\boldsymbol{\alpha}$ & $\begin{array}{c}\text { Signifikan? } \\
\text { (Ya/Tidak) }\end{array}$ \\
\hline Bersikap Agresif & 0,203 & 0,079 & Tidak \\
\hline Pelanggaran Biasa & 0,402 & 0,002 & Ya \\
\hline Kesalahan & 0,516 & $<0,001$ & Ya \\
\hline Penyimpangan & 0,387 & 0,003 & Ya \\
\hline
\end{tabular}

\section{Korelasi Norma Hukum Dengan Kelompok Variabel DBQ}

Pada Tabel 8. sebagian besar norma hukum berkorelasi signifikan dengan kelompok variabel DBQ kecuali dengan kelompok penyimpangan. Hal ini mungkin dikarenakan pertanyaan dalam kuesioner tidak ada yang merujuk kepada 
tindakan hukum seperti kesulitan mengendalikan kendaraan pada malam hari, menggunakan telepon genggam (menelepon) dan mengendarai mobil yang rusak, sehingga hasil tersebut adalah suatu hal yang wajar. Namun berbeda dengan dengan kelompok variabel bersikap agresif, pelanggaran biasa dan kesalahan yang memiliki indikator yang merujuk ke norma hukum seperti mengemudikan mobil dalam pengaruh minum-minuman keras, melewati batas kecepatan, menerobos lampu lalu lintas dan lain sebagainya, sehingga memiliki korelasi yang signifikan dengan norma hukum.

Tabel 8. Korelasi Antara Norma Hukum Dengan Kelompok Variabel DBQ

\begin{tabular}{|c|c|c|c|}
\hline Kelompok Variabel & $\begin{array}{c}\text { Koefisien Korelasi } \\
(\mathbf{r})\end{array}$ & $\boldsymbol{\alpha}$ & $\begin{array}{c}\text { Signifikan? } \\
\text { (Ya/Tidak) }\end{array}$ \\
\hline Bersikap Agresif & 0,307 & 0,015 & Ya \\
\hline Pelanggaran Biasa & 0,302 & 0,017 & Ya \\
\hline Kesalahan & 0,328 & 0,010 & Ya \\
\hline Penyimpangan & 0,169 & 0,120 & Tidak \\
\hline
\end{tabular}

\section{KESIMPULAN}

Berdasarkan hasil analisis hubungan pendidikan keluarga (norma) terhadap perilaku berkendara saat berlalu lintas maka dapat diambil kesimpulan sebagai berikut:

1. Beberapa norma yang diajarkan dalam keluarga berpengaruh terhadap perilaku pengendara bermotor pada saat berlalu lintas.

2. Terdapat hubungan positif antara norma agama dengan melakukan aksi stunt didalam perilaku berkendara sepeda motor.

3. Terdapat hubungan positif antara norma disiplin dengan pelanggaran kecepatan, kesalahan berlalu lintas dan melakukan aksi stunt didalam perilaku berkendara sepeda motor.

4. Terdapat hubungan positif antara etika dan sopan santun dengan pelanggaran kecepatan, kesalahan mengendalikan kendaraan dan melakukan aksi stunt didalam perilaku berkendara sepeda motor.

5. Tidak terdapat hubungan antara norma hukum dengan perilaku berkendara sepeda motor.

6. Terdapat hubungan positif antara norma agama dengan kesalahan dan penyimpangan didalam perilaku berkendara dengan mobil.

7. Terdapat hubungan positif antara norma disiplin dengan pelanggaran biasa dan kesalahan didalam perilaku berkendara dengan mobil.

8. Terdapat hubungan positif antara etika dan sopan santun dengan pelanggaran biasa, kesalahan dan penyimpangan didalam perilaku berkendara dengan mobil.

9. Terdapat hubungan positif antara norma hukum dengan bersikap agresif, pelanggaran biasa dan kesalahan didalam perilaku berkendara dengan mobil.

\section{DAFTAR PUSTAKA}

Anggraini, D. Studi Tentang Perilaku Pengendara Kendaraan Bermotor Di Kota Samarinda. eJournal SosiatriSosiologi. Vol. 1. No. 1 (Februari 2013): 10-19.

Bunawan, R. Perilaku Dosen dan Karyawan Universitas Tarumanagara dalam Mengemudikan Sepeda Motor. Skripsi, Universitas Tarumanagara, 2014.

Buwana, C. Perilaku Berlalu Lintas Masyarakat Jawa Di Kota Surakarta. Skripsi. Universitas Muhammadiyah, 2013.

Fardaniah, R. Angka Kematian di Indonesia Akibat Kecelakaan Mobil Tinggi (On-Line). Tersedia di www: https://otomotif.antaranews.com/berita/581510/angka-kematian-di-indonesia-akibat-kecelakaan-mobil-tinggi (5 Maret 2018).

Helmawati. Pendidikan Keluarga. Bandung: Remaja Rosdakarya, 2014.

Hendrati, L.Y., dan Hidayati, A. Analisis Risiko Kecelakaan Lalu Lintas Berdasar Pengetahuan, Penggunaan Jalur, Dan Kecepatan Berkendara. Jurnal Berkala Epidemiologi. Vol. 4. No. 2 (Juli 2016): 275-287.

Hidayah, N. Disiplin Lalu Lintas Pengendara Sepeda Motor Roda Dua Di Kecamatan Tampan Pekanbaru. Jurnal Sosiologi. Vol. 2 No. 1 (Februari 2015): 1-15.

Jailani, S. Teori Pendidikan Keluarga dan Tanggung Jawab Orang Tua dalam Pendidikan Anak Usia Dini. Jurnal Pendidikan Islam. Vol. 8. No. 2 (Oktober 2014): 90-102. 
Kristanto, A. Hubungan Lingkungan Pendidikan Dengan Prestasi Belajar Siswa Kelas II Jurusan Teknik Mekanik Otomotif SMK Se-Kabupaten Sleman. Skripsi, Universitas Negeri Yogyakarta, 2012.

Mansur. Pendidikan Anak Usia Dini dalam Islam. Yogyakarta: Pustaka Pelajar, 2005.

Muhammaddin. Kebutuhan Manusia Terhadap Agama. Jurnal Kajian Islam. No.1 (Juni 2013): 99-114.

Nonoatmodjo. Ilmu perilaku kesehatan. Jakarta: Rineka Cipta, 2010.

Nurdiansyah, D. Uji Validitas dan Reliabilitas (On-Line). Tersedia di www: http://www.statsdata.my.id/2011/12/ujivaliditas-dan-reliabilitas.html (6 Juli 2018).

Putranto, L.S, et.al. 2014. Motorcycle Rider Behaviour Of Tarumanagara University Lecturer And Employee. The $17^{\text {th }}$ FSTPT International Symposium, Universitas Jember, Jawa Timur.

Putranto, L.S, Pramana, A., Kurniawan, H. Hubungan antara Perilaku Pengemudi Sepeda Motor pada Berbagai Keadaan Lalu-Lintas dengan Karakteristik Pengemudi, Kendaraan dan Perjalanan. Jurnal Transportasi. Vol. 6. No. 1 (Juni 2006): 63-70.

Putranto, L.S, Rostiana. 2014. Studi Penanganan Perilaku Beresiko Pengemudi Sepeda Motor Indonesia. Penelitian Strategis Nasional, Universitas Tarumanagara, Jakarta.

Republik Indonesia. 2003. Undang-Undang No. 20 Tahun 2003 tentang Sistem Pendidikan Nasional Pasal 1.

Republik Indonesia. 2009. Undang-Undang No. 22 Tahun 2009 tentang Lalu Lintas dan Angkutan Jalan Pasal 29.

Republik Indonesia. 2012. Undang-Undang No. 12 Tahun 2012 tentang Pendidikan Tinggi.

Rezalti, D.T. Pengaruh Jenis Edukasi Terhadap Performansi Pengemudi dengan Karakter Risk Taker. Jurnal trasnportasi. Vol. 37. No. 1 (Januari 2016): 58-66.

Ritonga, R.Z., Boong, V.R., Listya Y. Hubungan Antara Nilai, Etika dan Norma Hukum Dalam Pelaksanaan PHK Di Indonesia. Jurnal Economia. Vol. 8. No. 1 (April 2012): 1-14.

Sadono, S. Budaya Tertib Berlalu-Lintas "Kajian Fenomenologis Atas Masyarakat Pengendara Sepeda Motor Di Kota Bandung”. Jurnal Komunikasi. Vol. 4. No. 1 (April 2016): 61-79.

Sarifudin, A. Astaga angka kecelakaan lalu lintas di Indonesia termasuk tinggi di dunia (On-Line). Tersedia di www: https://news.okezone.com/read/2017/09/14/340/1775815/astaga-angka-kecelakaan-lalu-lintas-diindonesia-termasuk-tinggi-di-dunia (3 Maret 2018).

Sukmadinata, N. Landasan Psikologi Proses Pendidikan. Bandung: Remaja Rodaskarya, 2004.

Syafputri, E. Jumlah motor dan mobil di jakarta tumbuh 12 persen tiap tahun (On-Line). Tersedia di www: http://www.antaranews.com/berita/473169/jumlah-motor-dan-mobil-di-jakarta-tumbuh-12-persen-tiap-tahun (24 Februari 2018).

Wawan. Teori dan pengukuran pengetahuan, sikap, dan perilaku manusia. Yogyakarta: Nuha Medika, 2011.

Wibowo, Agus. Pendidikan karakter. Yogyakarta: Pustaka Pelajar, 2012.

Yusuf, Syamsu. Psikologi Perkembangan Anak \& Remaja, Bandung: Remaja Rosdakarya, 2007. 